\title{
The Peeters house in Deurne by Gaston Eysselinck: a Flemish 'machine à habiter'
}

\author{
A. Verdonck \\ Vrije Universiteit Brussel, Department of Architectural Engineering, \\ Belgium
}

\begin{abstract}
Gaston Eysselinck (1907-1953), one of Belgium's famous Modernists, built the Peeters-Ceurels house in the Antwerp region in 1932. The house became a listed monument in 1995. It shows some resemblances to Le Corbusier's Maison Citrohan in the 1927 Weissenhofsiedlung in Stuttgart, with regard to the design, the construction of the façade and even the use of colour. This paper will examine the original materials and colour schemes used in the Peeters house as well as the process of restoration. In the archives one of Eysselinck's original design drawings for this house was rediscovered. It shows a peculiar colour pattern for the façades. On-site research revealed this original concept. The colour scheme developed by Eysselinck is inextricably linked to the international modern era. As pointed out in the projects of Le Corbusier, colour is prominent in the work of modern architects in general. Although Eysselinck's unusual colour pattern deserves our attention, it was painted over and forgotten. Technical problems with the plaster and many transformations have severely damaged the monument. To revitalise the original colour scheme of this significant house, a choice between maximal preservation of the historical material and durable technology had to be made. The historical research, fieldwork, lab research and restoration test strips backed up the final restoration proposals.

The results of this study contribute to the communication and appreciation of colour in modernism, a contribution in dealing with the white misunderstandings in our young architecture.
\end{abstract}

Keywords: modern era, colour scheme, architectural polychromy, restoration strategy, revitalisation. 


\section{Gaston Eysselinck and the international modern era}

Gaston Eysselinck (1907-1953) is one of Belgium's most famous architects from the modern era of the second generation. His educational trips to the Netherlands and especially his acquaintance with Le Corbusier's work had substantially influenced his oeuvre.

During two study tours to the Netherlands [2], the young Eysselinck visited Jacobus Johannes Pieter Oud's café De Unie (1925) in Rotterdam and the Schröder house (1924) of Gerrit Rietveld in Utrecht. He became thoroughly acquainted with the colour schemes of the De Stijl-movement, where the noncolours (black, white and tones of grey) and the primary colours (red, yellow and blue) are central elements. The drawings he has made during these trips are pointing towards his interest for the creations of de Amsterdamse School, the De Stijl-movement as well as for the Neue Sachlichkeit. One of the highlights was the main office of the Coöperatie De Volharding at Den Haag (1928) by Jan Buijs (fig.1, left). In a quick sketch Eysselinck made a detailed note of the colours of this façade [3]. Nevertheless, his major colour experience probably took place during his honeymoon in 1930 when he passed through Germany and visited the Weissenhofsiedlung in Stuttgart. The use of colour as an important component of modern architecture in these housings, in particular the two projects designed by Le Corbusier, was overwhelming. At the same time he became acquainted with the publication of the first volume of Le Corbusier's Oeuvre Complète, which had a tremendous influence on his career. Upon his return to Belgium, Eysselinck succeeded in implementing these foreign impressions and influences in his own way.
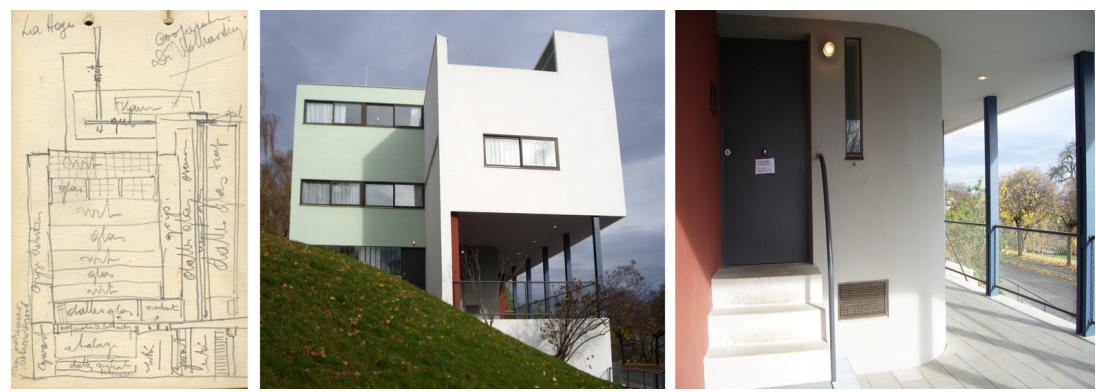

Figure 1: Sketch 'De Volharding' (1928, J. Buijs, Den Haag, the Netherlands (left), [CDesign museum Ghent, collection Gaston Eysselinck], 'Transformable Doppelwohnhaus' (1927, Le Corbusier, Weissenhofseidlung-Stuttgart, Germany) (middle and right), [photos (C Evi Corne, 2008].

\section{The Peeters house in Deurne: a variant to the 'Maison Citrohan'}

In 1932, Gaston Eysselinck built the Peeters-Ceurvels house in the Antwerp region. The family house is situated on a plot on the corner of the De Neufstraat 
and the Ter Rivierenlaan, a residential quarter of Deurne (Antwerp) (fig.2). The Peeters house is a variant of his own house in Ghent (1930-1931), a masterpiece with large spatial dynamics on a nearly impossible corner parcel. His interventions on compact corner lots, using the negative aspects of the parcel to maximum advantage, are innovative and authoritative in modernistic architecture of the second generation in Belgium. In 1935, the Italian architect $A$. Sartoris already mentioned the house in a retrospective work of the functional architecture [4].

Furthermore, the resemblances with Le Corbusier's Maison Citrohan for the 1927 Weissenhofsiedlung in Stuttgart are striking. The ideas of standardisation, mass production and maintenance of the modern machine, such as the French Citroën car, were introduced in this model, called the 'machine à habiter'.

The Peeters house is a Flemish example of Le Corbusier's machine à habiter: 'Like not one machine contains a superfluous cogwheel or chain, Eysselink's dwelling machine contains no superfluous table, chair or sofa [5].
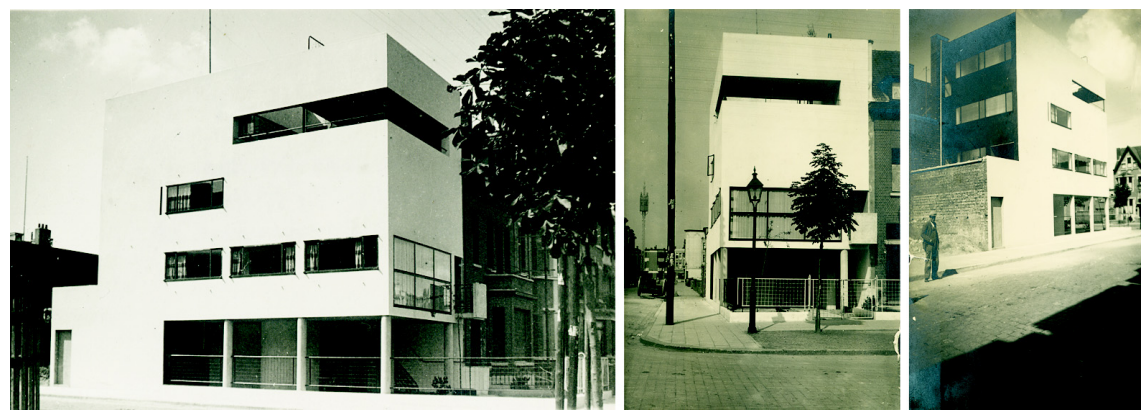

Figure 2: 'Peeters-Ceurvels' house (1932, G. Eysselinck, Antwerp, Belgium) - façade De Neufstraat (left), façade Ter Rivierenlaan (middle), black rear façade (right), [@Design museum Ghent, collection Gaston Eysselinck].

In the Citrohan concept, Le Corbusier established also the principles of his five Points of a New Architecture: pillars (pilotis), free plan (plan libre), free façade (façade libre), horizontal sliding windows (fenêtres en longueur) and the roof garden (toit terrasse) [6]. The Peeters house fulfilled undogmatically some of these principles. On the ground floor the round pillars achieve a floating expression of the mass, intensified by the dark coloured plinth. The plan is based on the idea of the free plan and the horizontal sliding windows in the rear façades of the Peeters house, creating perspective sights on the green neighbourhood, provide an interesting game of light and shades. Two roof gardens compensate the small inner space of the compact corner lot, give a surplus to the flat roof and restore the area of ground covered by the house. Eysselinck chooses for his own house in Ghent as well as for the Peeters house a clear split between the roof terrace and the solarium, which is situated higher up. In the two projects designed by Le Corbusier for the Weissenhofsiedlung in Stuttgart, only the roof terrace is conceived. 
On the ground floor the garage, the boiler-house and the inside staircases are situated, including a small courtyard, creating the third façade. The Dutch influence is apparent in the use of a spatial solution for the outside staircase to the first floor dwelling, a solution probably never used in Belgian terraced housing typology until then [7]. On the first floor, the large living room with a balcony, the dining-corner, the kitchen and appurtenances with a small terrace are situated, overlooking the neighbourhood. The inside-outside relation is increased by the two-storied living room and the presence of a cantilever terrace. As a box in a box, the workplace hangs in the space of the high living room. Behind the workplace, the second floor contains the master bedroom with bathand dressing room. Two large bedrooms with lavatory and the roof garden are situated on the third floor. A metal outer staircase gives entry to the solarium on top of the house [8].

\section{Colour scheme: white sculpture or pronounced polychromy?}

The Peeters house combines an innovating living program with a remarkable colour scheme. In the archives Eysselinck's design drawing for the colours of the façades of the Peeters house was rediscovered [9]. $\mathrm{T}$ his draft sketch makes mention of the colour scheme 'beige, rusty brown, black, white, blue and yellow' (fig.3, left). On the plans annotations are made with reference to characteristics of the plasterwork and the matching colours.
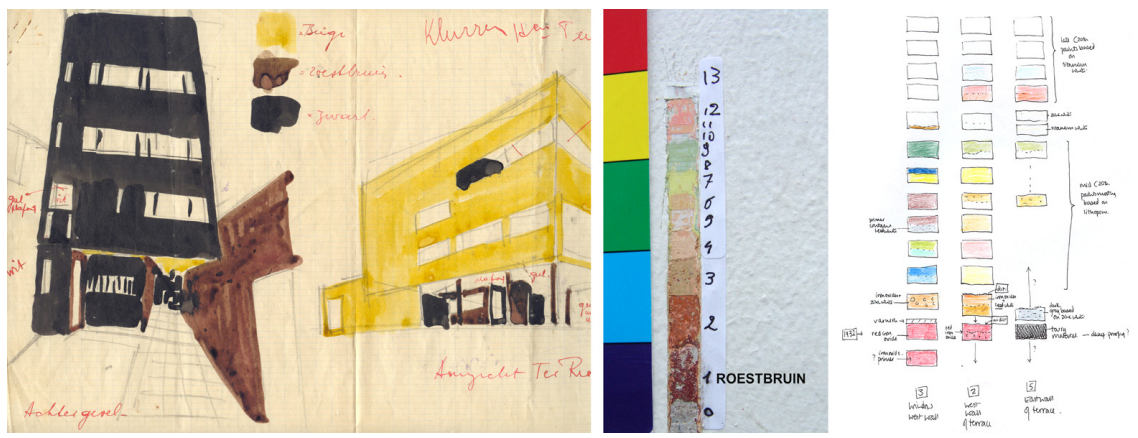

Figure 3: Eysselinck's design drawing of the Peeters house, [CDesignmuseum Ghent, collection Gaston Eysselinck, sd.] (left), exposure of the external wall planes, [Examino cvba, Ann Verdonck, 2005] (middle) and cross sections of the paint layers (right), [Claboratory analyst C. Hassal, London-England 2005].

Despite various efforts on several international discussions to settle definitively with the misconception of the white modernism, we must conclude that the colours of our young architecture are not known anymore and that we are deceived by the black and white photography. In the recent repertory of the Belgium architecture from 1830 to date, we still read: 'The Peeters house in 
Deurne (1932) and the Contryn-Van Hoogenbemt houses fit close to the white painted examples from the International Style [10]. Colour research conducted in 2005 on the Peeters house, puts the so-called 'white' modernism of this house in a different light.

Exposures were made on all external wall planes and attendant information was gathered about the used pigments of the paint. The results are surprising. The vertical parts of the façade along the De Neufstraat and the Ter Rivierenlaan (fig.2 left and middle) are originally carried out in beige (fig.3 left). The rear façade (fig. 2 right) is painted black with bitumen paint (fig.3 left). All horizontal planes, being the carport's ceiling and the sun terrace, are painted in bright yellow (fig.3 left). The volumes underneath the carport and on the terraces are originally painted black and rusty brown (fig.3 left). By the use of a polarised light microscope the original pigments were identified as yellow ochre (beige), iron oxide red (rusty brown), cadmium yellow (yellow) and bitumen (black) (fig.3 right). The lab analyses determined also a gritty texture that was mainly generated by the plaster with a frosted aspect of the paint (lime and oil).

The walls enclosing the outside staircase to the first floor are obviously considered by Eysselinck as a first step towards the interior: the surface is smoother and painted in a light colour (grey beige).

Moreover, the original metal framework was sampled: ultramarine on the windows and parapets, red on the framework of the back façade, rusty brown on the garage gate and olive green on the banisters of the outside staircase were exposed.

Lab analysis rectified this diversity of colours in the sample survey. It seems that the three façades in ochre were originally combined with a brown umber framework, while the black rear elevation originally had a red (iron oxide red) framework.

Although covered by several layers of more recent paint or plaster, the colour investigation on the Peeters house show a rare colour scheme, which still remains present.

\section{The challenges of the restoration programme}

The original finishing layers are submitted to an extensive investigation using on-site test strips. In 1932 the framed concrete construction, filled up with bricks, was plastered by a two-layered system of bad mortar. On a drawing of April $13^{\text {th }}$ 1932, the mortar is defined as 'granular beige and brown sprayed simili-cement' [11]. The so-called simili is a mixture of cement, lime, grinded stone and quartz granulate, where the colour is usually defined by the nature of the stone. The brown and beige simili in the Peeters house were not mixed in mass but simply painted in a daring palette of beige, rusty brown, black and yellow.

The different coefficients of expansion of the materials, thermal breaks and moisture problems are clearly dramatic to the old plasterwork. Besides, temperature peaks on the black painted façades of the building caused cracks and detached the plasterwork. In the seventies of the twentieth century, the damage to the original plasterwork of the two street façades was smuggled behind a white synthetic plaster. The other façades are covered with a thick package of paint 
layers. Zinc sheds were added at the upper side of the windows to prevent humidity of oozing through. These interventions override the architectural purity of the original concept and do not deal with the source of the damage.

\subsection{Test strips}

New plaster systems were conducted in restoration test strips. A first test strip was put on the street façade (test strip 1) and a second one on the roof garden façade (test strip 2). On test strip 1 the synthetic plaster (one synthetic layer of $0,4 \mathrm{~cm}$ ) and the original 1932 (two layers of bad mortar $2+0,5 \mathrm{~cm}$ ) were removed. This test revealed that it appears technically as well as economically unrealistic to remove successfully the synthetic plaster from the historical one. Besides, residue of the synthetic material remains in the old plaster, which creates attendant restrictions to the construction of a new plaster system.

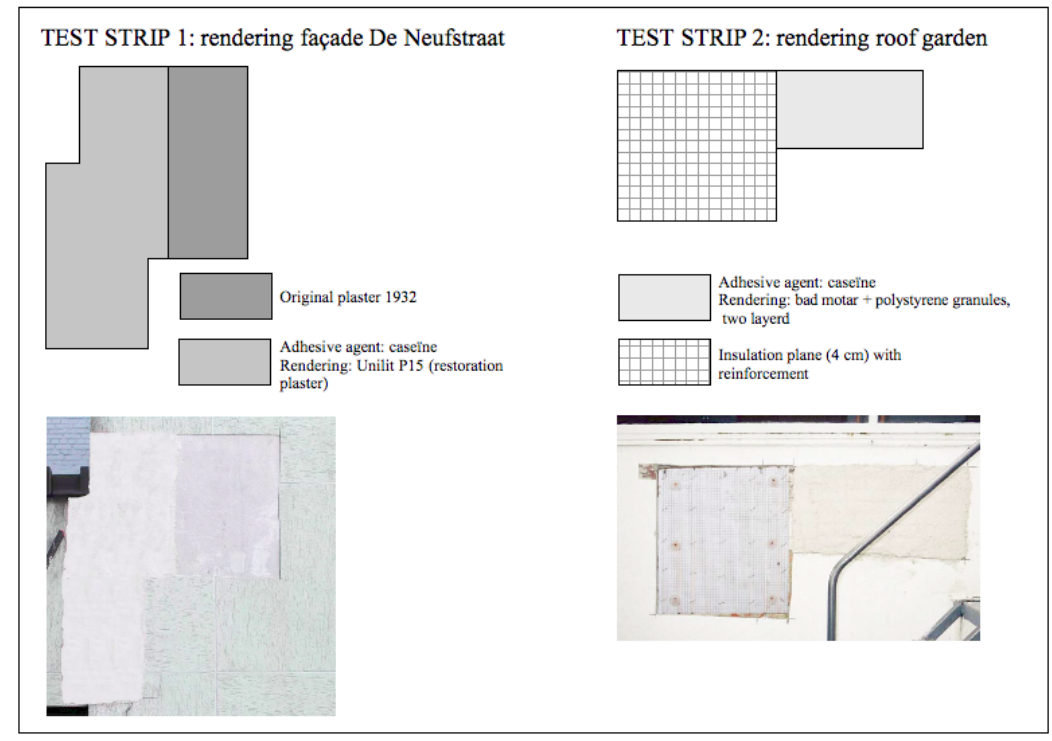

Figure 4: $\quad$ Test strips of the rendering.

On test strip 2 only the original plaster, although covered by 13 paint layers, had to be removed. After removing all plaster layers up till the masonry, new lime plaster systems have been tested on the exposed and prepared (adhesive layer of casein) masonry. Commercial renderings (Unilit P 15 \& Remmers Aisit Grondeerputz WTA) on a slaked lime base were plastered on the casein. The opportunity to increase the heat-resistance by reducing the thermal breaks, was tested in strip 2: a two-layered rendering (bad mortar) mixed with polystyrene granules was put on one part of the strip, whereas a reinforced insulation sheet of $4 \mathrm{~cm}$ was attached to the other part. On top of these different renderings, commercial finishing plasters (Unilit P 40, Remmers Aisit Saneerputz), artisan lime plasters and bad mortars were applied. 


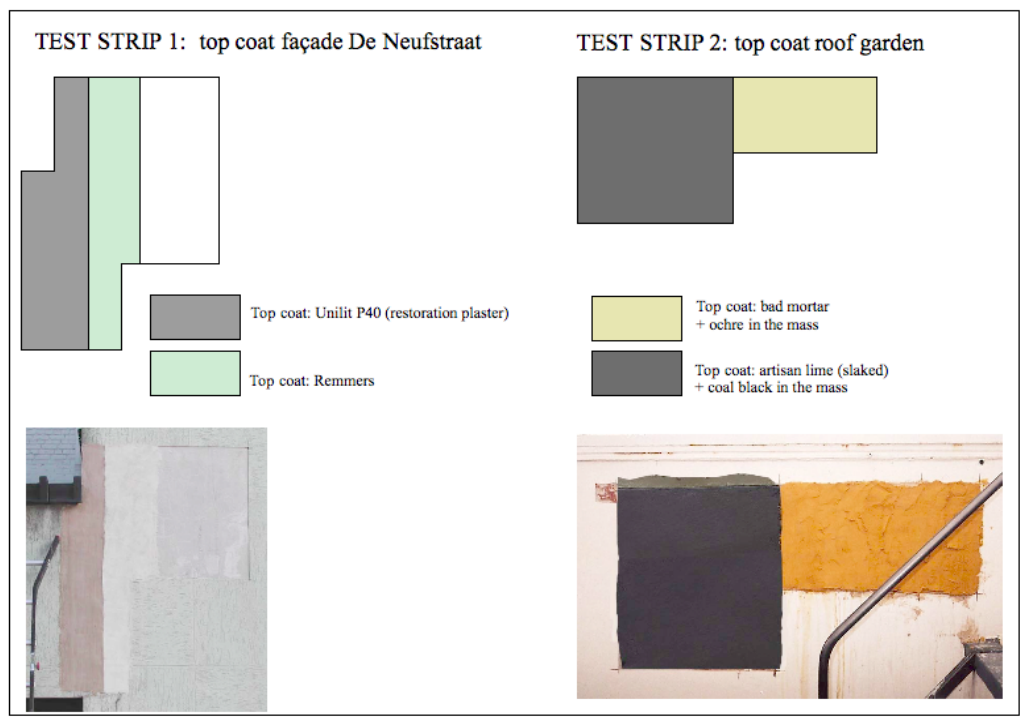

Figure 5: $\quad$ Test strips of the top coat.

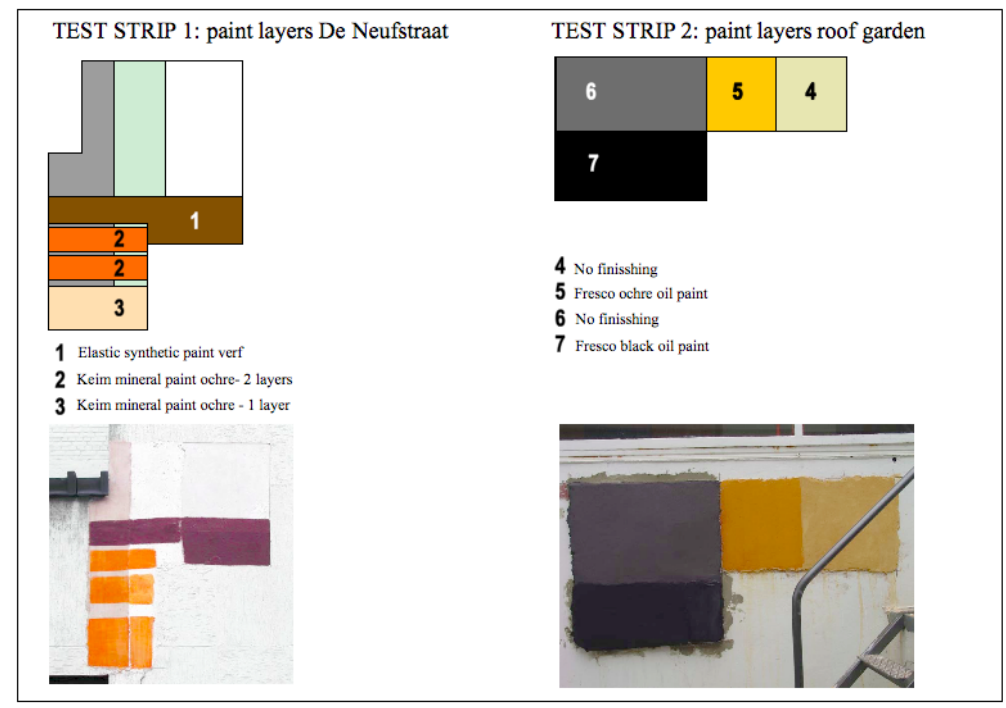

Figure 6: Test strips of the paint.

To conclude, series of paint coatings, going from flexible synthetic paint to artisan fresco paintings, were tested on site and optimized in the workshop. The best method to sustain the right tone, glimmer and covering was reached by painting with lime paint and colourfast pigments. The intensive black colour of the original bitumen was reached by applying in fresco a thin layer of oil paint on the wet top layer of in the mass coloured plaster. The result does not only 
guarantee the durability, but it is also strongly linked to the original concept of colour and texture by Eysselinck.

\subsection{The new plaster system}

The original plaster is severely deteriorated. The choice between maximum preservation of the existing finishing versus the removal because of technical reasons is essential. An attendant problem is related to the black façades. Black coloured façades are subjected to extreme temperature peaks, causing severe cracks.

The plaster systems were evaluated and the different parameters were lined up in a decision matrix. A difficult choice had to be made, taking into consideration the expressive original concept by Eysselinck, technical construction aspects such as the issue of the black façade and the owner's request to create an economic and durable solution. Two options were restrained. The first option was to remove all plaster, inspect thoroughly the underlying masonry and concrete structure, and apply a new bad mortar, comparable with the one of 1932 but with an insulating rendering. The second option was to keep all historic layers (plaster of 1932, synthetic plaster of the seventies and the colour package) and ad a reinforced insulating sheet $(4 \mathrm{~cm})$ finished by a thin commercial lime layer [12].

Taking into account the original aspect of the plaster, the thickness of the package versus the architectural details and the durability, the first option was given preference. Nevertheless, the second option was finally erected because of the overriding importance of maximum preservation of the existing finishing and the benefit of the high insulation factor. The original colour scheme was revived. To control the cracks, the new black plasterwork was executed in different fields, plastered in separate planes and sealed with black silicones.

\section{Conclusions}

The colour investigations and material-technical research throw a new light on the polychromy of the Peeters house. Eysselinck creates here an unusual colour
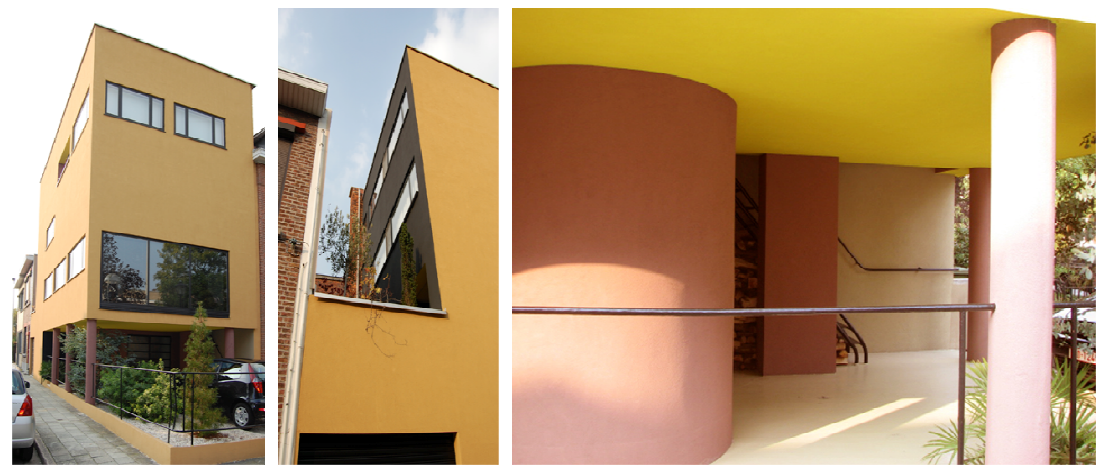

Figure 7: After restoration: street façades (left), rear façade (middle), carport (right). 
scheme, which deserves our attention. Behind a white coloured façade a remarkable colour concept appears. By means of colour interventions Eysselinck manipulates the volume of the dwelling. Some planes are accentuated by rusty brown or black, whereas others are dematerialised by beige. Still in this day and age, this remarkable colour scheme is painted over and forgotten. However, the results of this colour and material-technical research contribute to the communication and the valuation of colour in the modernism. It is time to put behind the lot of "white" misunderstandings. By thorough research and soundly based restoration strategies the original colour palette can revive and survive.

\section{References}

[1] Decree of protection (03.04.1995), published in the Statute Book of Belgium (08.06.1996).

[2] In August 1927 the destination is Rotterdam, Amsterdam, Hilversum, Utrecht and Breda. In September 1929 the trip goes from Ghent to Amsterdam by train, then by bicycle to Delft, Rijswijk, Den Haag, Wassenaar (Park Kievit), Leiden, Haarlem, Bussum, Hilversum and Utrecht.

[3] Design museum Ghent, collection Gaston Eysselinck, sd.

[4] Sartoris, A., Gli Elementi dell' Architettura Funzionale. Sintesi panoramica dell'architettura moderna, Uitgeverij: Milan, 1932.

[5] Cantré, W., De Woonmachine - Gaston Eysselinck, La Cité: Brussels, vol. 11, no. 7, 1933.

[6] In 1920-22 Le Corbusier designed the Maison Citrohan as a prototype of a single-family house. The projects of the Weissenhofsiedlung illustrate a pure, well-proportioned application of his 1922 Citrohan project.

[7] Dubois, M., Gaston Eysselinck House in Ghent (1930-1931). A white box in a classical city block, Architect Gaston Eysselinck 1907-1953, Uitgeverij: Design museum Ghent, 2003.

[8] In the seventies, the Peeters house was modified. Upon the ground floor a flat roof was placed to organise an extra garage. A more radical change to the original concept was the removal of the cantilever terrace on the first floor and the creation of an extra room on the roof terrace (third floor). Moreover, a part of the original metal windows were replaced by aluminium ones.

[9] Design museum Ghent, collection Gaston Eysselinck.

[10] Van Loo, A. et al, Repertorium van de Architectuur in België van 1830 tot heden, Uitgeverij: Antwerp, pp. 304-305, 2003.

[11] Design museum Ghent, collection Gaston Eysselinck, drawing of April 13th 1932: 'gegraineerde beige en bruine (simili) cement specie bespuiting'.

[12] Decision makers: research team: Ann Verdonck \& Hugo VandenBorre (Examino cvba), restoration architect: Sofie Beyen, restoration consulter: Elke Denissen (department of Monuments and Sites of the Flemish Government) and the owner Erik Vangrieken. 